\title{
ANALISIS CORPORATE CITIZENSHIP DAN HAK ASASI MANUSIA TERHADAP ISU EKSPLOITASI LINGKUNGAN PADA FILM "SEXY KILLERS" 1
}

\author{
Hanako Fatimah Pertiwi \\ Fakultas Ilmu Administrasi Universitas Indonesia \\ Komplek FISIP Universitas Indonesia, J1. Prof. Dr. Selo Soemardjan, Kota Depok \\ hanako.fatimah81@ui.ac.id
}

\begin{abstract}
Corporate responsibility regarding human rights in Indonesia is important because companies that violate these rights are in violation of existing environmental laws. One documentary film in Indonesia entitled "Sexy Killers" shows the lack of attitude and responsibility of one PLTU company in Indonesia in conducting its business, causing human rights violations. The film analyzed using descriptive qualitative analysis tells the story of environmental exploitation due to the construction of the PLTU in Kalimantan which results in negative externalities ranging from lack of clean water, environmental pollution, respiratory diseases to death. The implementation of the law does not go well. There are already regulations on environmental law in Indonesia. This case was analyzed with the concept of human rights, four faces of corporate citizenship and sustainable development. The results in this writing is company have not achieved good corporate citizenship because they only prioritize profits without concern for other stakeholders.
\end{abstract}

Keywords: Corporate Citizenship; Environmental Law; Sustainable Development; Human Rights

\begin{abstract}
Abstrak
Tanggung jawab perusahaan tentang hak asasi manusia di Indonesia penting dilakukan karena perusahaan yang melanggar hak tersebut berarti melanggar hukum lingkungan yang ada. Salah satu film dokumenter di Indonesia yang berjudul "Sexy Killers" menunjukkan kurangnya sikap dan tanggung jawab salah satu perusahaan PLTU di Indonesia dalam menjalankan bisnisnya sehingga menyebabkan pelanggaran HAM. Film yang dianalisis dengan menggunakan analisis kualitatif deskriptif tersebut bercerita mengenai eksploitasi lingkungan akibat pembangunan PLTU di Kalimantan yang mengakibatkan eksternalitas negatif mulai dari kekurangan air bersih, pencemaran lingkungan, penyakit pernapasan hingga kematian. Implementasi hukum tidak berjalan dengan baik meskipun sudah ada peraturan hukum lingkungan di Indonesia. Kasus ini dianalisis dengan konsep HAM, four faces of corporate citizenship dan sustainable development. Hasil yang ditemukan adalah bahwa perusahaan belum mencapai corporate citizenship yang baik karena hanya mementingkan keuntungan semata tanpa mempedulikan stakeholders lainnya.
\end{abstract}

Kata Kunci: Corporate Citizenship; Hukum Lingkungan; Pembangunan Berkelanjutan; Hak Asasi Manusia

\footnotetext{
${ }^{1}$ Merupakan artikel hasil penelitian yang dilakukan terhadap fenomena eksploitasi lingkungan dalam film dokumenter berjudul "Sexy Killers". Film diakses dari: Channel Youtube Watchdoc Image: https://www.youtube.com/watch?v=qlB7vg4I-To
} 


\section{A. Pendahuluan}

Adanya film dokumenter "Sexy Killers" yang dirilis oleh Watchdoc Image pada tanggal 5 April 2019 mempertontonkan bahwa industri batubara untuk PLTU menimbulkan masalah lingkungan, sosial, ekonomi, dan kesehatan. Hingga tanggal 22 Mei 2019 film pendek yang sudah ditonton sekitar 22 juta kali oleh pengguna YouTube ini menarik perhatian bahwa perusahaanperusahaan tambang saling berhubungan antara pejabat, pengusaha, serta calon yang maju dalam presiden dan wakil presiden tahun 2019 (Syahni, 2019). Masalahmasalah yang ada dalam film menggambarkan kurangnya kepedulian perusahaan terhadap dampak negatif yang ditimbulkan akibat kegiatan dalam industri batubara yang mereka lakukan, mulai dari kekurangan air bersih, pencemaran lingkungan, penyakit pernapasan hingga kematian.

Dalam film tersebut, terlihat para aktivis dan rakyat telah memperjuangkan hak-hak mereka dengan usaha berdemo, bernegosiasi dan menuntut haknya agar perusahaan memperhatikan kondisi mereka saat itu. Dalam UU No. 32 Tahun 2009 tentang Perlindungan dan Pengelolaan Lingkungan Hidup sudah diatur bahwa lingkungan hidup yang baik dan sehat merupakan hak asasi setiap warga negara Indonesia sesuai dengan Pasal 28H UUD Negara Republik Indonesia Tahun 1945.

Dalam menganalisis kasus tersebut, digunakan beberapa konsep dan teori yang berkaitan dengan masalah lingkungan di Indonesia serta pertanggungjawaban perusahaan. Konsep tentang masalah lingkungan tersebut sudah tercatat dan berdiri lama di Indonesia dalam rangka untuk melindungi kepentingan bersama. Masalah tentang pertanggungjawaban perusahaan mengenai masalah lingkungan juga dapat ditinjau dengan the four faces of corporate citizenship dari Caroll yang melihat dari sisi etika, hukum, ekonomi, dan filantropi (Carroll, 2003).

Dalam artikel jurnal yang berjudul Perlindungan atas Hak Lingkungan Hidup yang Baik dan Sehat di Era Globalisasi (Rochmani, 2015) telah dibahas bahwa kerusakan lingkungan hidup bisa mengakibatkan kehidupan masyarakat terganggu. Dalam hal ini, hak atas lingkungan hidup yang baik dan sehat merupakan bagian dari HAM dan pelanggaran atas hal tersebut merupakan pelanggaran HAM dan hal tersebut merupakan kejahatan lingkungan.

Selain itu juga terdapat jurnal berjudul Arah Hukum Politik Lingkungan di Indonesia (Siombo, 2013) yang membahas bahwa keikutsertaan pemerintah Indonesia di konvensi internasional dalam bidang lingkungan tidak selalu menunjukkan komitmen pemerintah Indonesia untuk menerapkan konsep Pembangunan Berkelanjutan seperti yang dicanangkan dunia. Dengan kekayaan sumber daya alam yang Indonesia miliki, kehidupan rakyat Indonesia seharusnya bisa menjadi lebih baik, namun negara belum mampu mengelola kekayaan alam tersebut. Pemerintah harus fokus pada pengawasan pelaksanaan pembangunan, mempercepat terwujudnya pemerintahan yang bersih sehingga pembangunan berkelanjutan yang memperhatikan keseimbangan ekonomi, lingkungan dan sosial budaya dapat terwujud demi mencapai kesejahteraan rakyat.

Dalam jurnal yang berjudul Audit Lingkungan sebagai Perwujudan Tanggung Jawab Sosial Perusahaan yang dibuat oleh Ambarini, menyatakan bahwa audit lingkungan perlu dilakukan sebagai bentuk tanggung jawab sosial perusahaan. Perusahaan yang memiliki tujuan utama untuk mengambil keuntungan untuk pemegang saham juga harus memiliki pandangan terhadap paradigma tanggung jawabnya dari shareholders menjadi tanggung jawab sosial kepada stakeholders (Ambarini, 2011).

Kurangnya pertanggungjawaban dan kepedulian dari perusahaan batubara tersebut perlu ditinjau lebih lanjut apabila melihat hukum lingkungan di Indonesia dan juga hak asasi manusia dan tanggung jawab 
perusahaan. Dengan menganalisis permasalahan isu hukum lingkungan dan tanggung jawab perusahaan dalam film "Sexy Killers", dapat dilihat dampakdampak negatif apa saja yang terjadi akibat pembangunan PLTU terhadap masyarakat sekitar. Dari film juga dapat ditinjau lebih lanjut mengenai seberapa besar rasa peduli dan tanggung jawab perusahaan PLTU terhadap masyarakat dengan menganalisis film dari teori the four faces of corporate citizenship dari Caroll. Hal inilah yang menjadi state of the art dan kebaruan dari penelitian ini dari penelitian yang sudah ada sebelumnya, karena menggunakan studi kasus terhadap fenomena terbaru yang ditampilkan dalam film dokumenter berjudul "Sexy Killers" tersebut. Penelitian ini akan mengangkat permasalahan mengenai analisis corporate citizenship dan hak asasi manusia terhadap isu eksploitasi lingkungan pada film "Sexy Killers"?

\section{B. Metode Penelitian}

Metode analisis deskriptif digunakan dengan cara mencari sumber data sekunder, di antaranya adalah dengan mengambil studi literatur berupa jurnal, artikel, berita, undang-undang, dan buku yang relevan dengan tema yang ingin dibahas. Sumbersumber yang relevan tersebut akan membantu dalam menghasilkan analisis yang lebih tajam dan mendalam.

Film dokumenter digunakan sebagai data sekunder untuk dianalisis dengan cara menggunakan metode content analysis. Menurut Marying (2010), content analysis kualitatif merupakan sekumpulan analisis teks sistematis dari tidak hanya konten yang berwujud nyata tapi juga ide tema dan inti yang ditemukan dalam teks sebagai konten utama. Aspek komunikasi yang tidak dapat disampaikan melalui print teks, dapat disampaikan melalui audio atau video (Drisko, James W. \& Maschi, n.d.). Metode ini dapat digunakan untuk data visual seperti film dokumenter.

Video sebagai sumber utama menjelaskan mengenai fenomena kerusakan lingkungan oleh perusahaan dapat dikaji dengan menggunakan literatur dalam sudut pandang hak asasi manusia dalam hal hak untuk mendapatkan lingkungan yang sehat dan bersih. Kemudian konsep the four faces of corporate citizenship dari Caroll juga akan diambil dari jurnalnya sendiri. Selain itu akan dibahas mengenai hak asasi manusia akan udara yang sehat dalam kehidupannya serta mengenai perusahaan yang memegang prinsip pembangunan secara berkelanjutan.

\section{Hasil dan Pembahasan}

\section{Undang-Undang yang Berkaitan dengan Hak Asasi Manusia atas Lingkungan Hidup}

Dalam Undang-Undang Republik Indonesia Nomor 32 Tahun 2009 tentang Perlindungan dan Pengelolaan Lingkungan Hidup dinyatakan bahwa lingkungan hidup yang baik dan sehat merupakan hak asasi setiap warga negara Indonesia sesuai dengan Undang-Undang Dasar Negara Republik Indonesia Tahun 1945. Selain itu disebutkan bahwa audit lingkungan hidup dilakukan untuk menilai ketaatan penanggung jawab usaha dan/atau kegiatan terhadap persyaratan hukum dan kebijakan yang ditetapkan oleh pemerintah. Oleh karena itu, perusahaan harus melakukan audit lingkungan hidup sebagai dasar untuk menghormati hak asasi setiap warga negara Indonesia.

Dalam pasal 47 ayat (1) UU RI No. 32 Tahun 2009 juga disebutkan bahwa setiap usaha dan/atau kegiatan yang berpotensi menimbulkan dampak penting terhadap lingkungan hidup, ancaman terhadap ekosistem dan kehidupan, dan/atau kesehatan dan keselamatan manusia wajib melakukan analisis risiko lingkungan hidup. Sesuai yang tercantum dalam pasal tersebut, maka perusahaan batubara wajib untuk melakukan analisis risiko lingkungan hidup demi kelangsungan hidup manusia dalam hal kesehatan.

Berdasarkan Bab XII UU tersebut, maka Menteri, gubernur, bupati/walikota wajib mengawasi ketaatan dari penanggung 
jawab usaha atau kegiatan sesuai dengan yang ditetapkan dalam hal perlindungan dan pengelolaan lingkungan hidup. Dalam melaksanakan pengawasan, Menteri, gubernur, atau bupati/walikota menetapkan pejabat pengawas lingkungan hidup yang merupakan pejabat fungsional. Sementara itu, dalam film dokumenter Sexy Killer menyorot Luhut Binsar Panjaitan sebagai Menteri Koordinator Maritim sebagai salah satu pengusaha PT Toba Bara Sejahtra di Kalimantan yang memiliki empat anak perusahaan dan 50 tambang. Luhut yang sebagai Menteri dan juga sebagai pengusaha menanggapi film dokumenter tersebut tidak benar dan merupakan sebuah karya dari orang tidak punya kerjaan (Taher, 2019).

Indonesia memiliki UU No. 39 Tahun 1999 mengenai Hak Asasi Manusia. Dalam Bab II Asas-asas dasar pasal 2, berisi bahwa Negara RI mengakui dan menjunjung tinggi hak asasi manusia dan kebebasan dasar manusia sebagai hak yang secara kodrati melekat pada dan tidak terpisahkan dari manusia, yang harus dilindungi, dihormati, dan ditegakkan demi peningkatan martabat kemanusiaan, kesejahteraan, kebahagiaan, dan kecerdasan serta keadilan. Dalam Bab III HAM dan Kebebasan Dasar Manusia Pasal 9 ayat (3) berisi bahwa setiap orang berhak atas lingkungan hidup yang baik dan sehat. (Republik Indonesia, 2019). Hak-hak tersebut telah disalahgunakan karena adanya proses eksploitasi sumber daya alam mengakibatkan banyak penduduk Indonesia kehilangan hak atas tanah. Perusakan lingkungan sebagai salah satu akibatnya mempersulit hak atas pangan dan air (Indonesia, n.d.).

WALHI adalah organisasi yang bergerak di bidang lingkungan, dari tahun 2003 mereka berkampanye bahwa hak atas lingkungan hidup yang baik dan sehat sebagai bagian dari hak asasi manusia. Isu lingkungan hidup dibajak dengan berbagai hal yang "green" agar melanggengkan konflik antara sumber daya alam dan melanggar HAM (Ayu, n.d.). Dalam hal ini perusahaan PT Toba Bara Sejahtra memiliki pilar pada program CSR-nya yaitu lingkungan sebagai fokusnya. Mereka memiliki fokus seperti menerapkan program "go green", menerapkan program untuk pemeliharaan sumur bor, pompa air, dan rencana distribusi tanah untuk air bersih (PDAM), serta melakukan program pengelolaan limbah.

\section{The Four Faces of Corporate Citizenship}

Perhatian ilmiah bergeser dari konsep CSR ke konsep "kewargaan perusahaan (Corporate Citizenship/CC)". Konsep CC merupakan suatu kendaraan untuk perubahan sosial dan transformasi perusahaan. Fokus CC terbatas pada hubungan perusahaan-komunitas. $\mathrm{CC}$ juga dipandang sebagai konsep yang lebih sempit, konsep yang memiliki kesukarelaan lebih besar daripada CSR. Berikut merupakan konsep yang diambil dari jurnal Archie B. Carroll yang berjudul The Four Faces of Corporate Citizenship. Konsep ini dapat disebut juga dalam jurnalnya sebagai hal yang diharapkan perusahaan untuk memenuhi tanggung jawabnya sebagai bagian dari masyarakat. Corporate citizenship memiliki empat hal penting, di antaranya adalah ekonomi, hukum, etika, dan filantropi. Disebutkan bahwa CC yang baik diharapkan untuk:
a. Menguntungkan (memenuhi tanggung jawab ekonomi perusahaan)

Organisasi bisnis diharapkan menghasilkan penghasilan yang cukup untuk membayar tagihan dan menghasilkan hadiah mereka investor mereka. Warga korporat yang baik menghasilkan cukup uang sehingga investor mereka menerima pengembalian yang kuat investasi mereka dan para pemangku kepentingan lainnya yakin akan kelangsungan bisnis dan aliran produk, layanan, pekerjaan, dan manfaat lain yang diberikan oleh perusahaan. Namun terdapat beberapa tanggung jawab lainnya selain hanya mencari keuntungan semata. Perusahaan 
berhutang kepada karyawan dan komunitas mereka dan terkadang mereka harus mengorbankan keuntungan demi membuat segalanya lebih baik untuk karyawan dan komunitas mereka. Karena itu, laba merupakan sine qua non (pengaruh/sebab) kewarganegaraan perusahaan yang efektif.

Dalam kasus film dokumenter "Sexy Killer", perusahaan sudah memenuhi tanggung jawab ekonomi perusahaan karena telah menghasilkan pendapatan yang tinggi dengan menyediakan sumber penerangan terhadap warga negara Indonesia. PT Toba Bara Sejahtra memberikan dampak positif kepada perusahaannya dengan memberikan keuntungan yang besar terhadap perusahaan, yaitu disebutkan dalam kontan.co.id (2019), PT Toba Bara Sejahtra memberikan pertumbuhan kinerja keuangan tahun 2018 dengan peningkatan $41,11 \%$ menjadi US\$ 438,44 juta dari tahun sebelumnya, yaitu US\$ 310,71 juta. Pendapatan ini berasal dari penjualan batubara keluar negeri dan pasar domestik yang samasama turut tumbuh dibandingkan tahun lalu (Kartika, 2019).

\section{b. Mematuhi hukum (memenuhi tanggung jawab hukumnya)}

Warga korporat yang baik, sama seperti individu, juga diharapkan untuk mematuhi hukum. Salah satu cara berpikir tentang hukum adalah melihatnya sebagai etika terkodifikasi. Jika etika bisnis adalah tentang apa yang benar, baik, dan adil di ranah komersial, hukum dirancang oleh anggota parlemen untuk mewujudkan standar-standar dalam hal kinerja bisnis.

Perhatian khusus untuk bisnis yang ingin menjadi warga korporat yang baik adalah undang-undang dan hukum yang dirancang untuk mengatur hubungan mereka dengan pemangku kepentingan utama seperti konsumen, karyawan, masyarakat, dan lingkungan alam. Jika bisnis ingin dianggap dan dikagumi sebagai warga korporat yang baik, mereka mematuhi undang-undang ini dan mengintegrasikan kepatuhan hukum ke dalam strategi perusahaan dan manajemen operasional mereka.

Film dokumenter "Sexy Killers" merepresentasikan bahwa perusahaan PT Toba Bara Sejahtra memang sudah tahu mengenai aturan hukum yang berlaku karena mereka merupakan perusahaan terbuka (Tbk) yang dapat dibeli sahamnya oleh masyarakat pada bursa efek Indonesia. Mereka taat akan beberapa hal, seperti dalam hal pajak. Namun terdapat beberapa isu penting mengenai batas wilayah penambangan dengan wilayah lokasi warga serta pemulihan untuk lingkungan atas kerusakan yang mereka lakukan. Perusahaan harus memenuhi pemangku kepentingan yang juga merupakan pemerintah sebagai agen publik yang bertugas menegakkan standar perilaku dalam bidang bisnis. Aturan pemerintah tersebut dianggap sebagai beban perusahaan yang tidak adil dan menghambat keuntungan dari perusahaan dan kinerja perusahaan karena terlalu banyak yang harus diperhatikan dalam hal lingkungan dan aturan-aturan lain yang memberatkan perusahaan terkait dengan aspek keadilan, pengaturan kerja yang adil dan merata dan lain sebagainya yang dianggap menyulitkan perusahaan. Oleh karena hal tersebut, PT Toba Bara Sejahtra tidak melaksanakan hukumnya sebagai bentuk bertanggung jawab atas kerusakan yang mereka lakukan sehingga dalam film tersebut, pemerintah perlu mempertanyakan tanggung jawab dan menegur mereka akan hal tersebut (Watchdoc Image, 2019). 
c. Terikat dengan tingkah laku yang etis (memberikan respon terhadap tanggung jawab etis)

Bisnis yang ingin dianggap sebagai warga korporat yang patut dicontoh tidak hanya harus sukses secara ekonomi dan berfungsi sesuai dengan hukum, tetapi mereka juga berusaha untuk beroperasi dengan cara yang etis. Mematuhi hukum berarti beroperasi pada tingkat minimum perilaku yang dapat diterima. Warga korporat yang jujur harus melampaui sekadar kepatuhan terhadap hukum.

Ada beberapa alasan untuk hal ini. Pertama, undang-undang dan peraturan sering mencerminkan "minimum" yang dapat disetujui oleh anggota parlemen dalam pemberian dan manuver politik. Oleh karena itu, undang-undang tersebut mungkin tidak berada pada level atau standar yang benar-benar diperlukan untuk melindungi berbagai kelompok pemangku kepentingan. Alasan lain mengapa undang-undang mungkin tidak memadai adalah bahwa undang-undang mungkin tidak membahas semua masalah sosial yang perlu ditangani. Etika yang sehat diperlukan karena hukum mungkin belum disahkan untuk mencerminkan pemikiran masyarakat tentang beberapa masalah untuk beberapa tahun mendatang.

Kasus dalam film tersebut menggambarkan bahwa perusahaan yang menyebabkan kerusakan lingkungan hidup belum memiliki pemikiran etis karena tidak memperhatikan kepentingan rakyat yang merupakan stakeholder dalam prinsip corporate citizenship. Dampak kesehatan yang diberikan kepada masyarakat di Kalimantan tidak diakui sebagai akibat dari aktivitas perusahaan. Etika perlu disadari oleh perusahaan terkait dengan perilaku bisnisnya yang merugikan masyarakat. Perusahaan yang baik tidak hanya memenuhi hukum saja yang suatu waktu dapat tertinggal oleh jaman karena tidak diperbaharui secara cepat, tapi juga memenuhi dan menanamkan etika dalam perusahaan, mengetahui mana yang baik dan buruk untuk dilakukan serta melaksanakannya. Dalam hal ini, manajer perusahaan berperan besar sebagai manajer moral untuk menjalankan bisnis yang penuh dengan etika karena mereka merupakan panutan bagi para bawahnya. Manajer harus berhati-hati mengenai keputusannya agar dapat membentuk karakter perusahaan yang baik. PT Toba Bara Sejahtra untuk itu perlu memiliki manajer yang benar-benar memperhatikan sisi etika perilaku perusahaan dalam menjalankan bisnisnya, tidak hanya sekadar mematuhi hukum atau mencari keuntungan semata.

d. Melakukan dan terikat dengan kegiatan filantropis (terikat dengan kontribusi korporasi)

Filantropi diyakini secara umum sebagai keinginan untuk membantu umat manusia melalui tindakan amal, baik yang dilakukan oleh warga negara swasta, yayasan, atau perusahaan. Filantropi termasuk tindakan masyarakat untuk meningkatkan kualitas hidup dan untuk memastikan masa depan yang lebih baik. Warga negara swasta atau perusahaan yang baik diilhami oleh rasa amal iniperasaan meningkatkan kehidupan untuk yang lain. Warga korporat yang baik "memberikan kembali" kepada komunitas tempat mereka tinggal atau kepada yang tetap memelihara kantor mereka. Bisnis memiliki kewajiban untuk memberikan sesuatu kepada komunitas yang mendukung mereka.

PT Toba Bara Sejahtra dalam situsnya memiliki beberapa pilar dalam program filantropinya atau mereka sebut dengan corporate social responsibility (CSR), di antaranya adalah kesehatan, pendidikan, dan 
lingkungan. PT Toba Bara Sejahtra juga menampilkan beberapa kegiatan CSR nya melalui foto-foto atau publikasi setiap tahunnya. Kebanyakan foto dari kegiatan tersebut adalah kegiatan edukasi, sedikit menangani masalah kesehatan. Meskipun ada beberapa publikasi mengenai kepedulian perusahaan terhadap masalah kesehatan dalam program CSR-nya, namun kepedulian tersebut tidak pada warga masyarakat yang berada di wilayah Kalimantan atau yang terkena dampak akan kegiatan penambangan yang merusak lingkungan tersebut (Toba Bara, n.d.).

\section{Pembangunan Berkelanjutan}

Konsep pembangunan berkelanjutan didasarkan pada konsep pembangunan (pembangunan sosial-ekonomi sejalan dengan kendala ekologis), konsep kebutuhan (redistribusi sumber daya untuk memastikan kualitas hidup untuk semua) dan konsep generasi masa depan (kemungkinan penggunaan sumber daya jangka panjang untuk memastikan kualitas hidup yang diperlukan untuk generasi mendatang). Inti dari konsep pembangunan berkelanjutan berasal dari konsep triple bottom line, yang menyiratkan keseimbangan antara tiga pilar keberlanjutan, yaitu keberlanjutan lingkungan yang berfokus pada menjaga kualitas lingkungan yang diperlukan untuk melakukan kegiatan ekonomi dan kualitas hidup masyarakat, keberlanjutan sosial berupaya untuk memastikan hak asasi manusia dan kesetaraan, pelestarian identitas budaya, penghormatan terhadap keanekaragaman budaya, ras dan agama, dan keberlanjutan ekonomi yang diperlukan untuk memelihara modal alam, sosial dan manusia yang diperlukan untuk pendapatan dan standar kehidupan. Pembangunan berkelanjutan yang lengkap dicapai melalui keseimbangan antara semua pilar ini (Klaris, 2018).

Sedangkan, definisi keberlanjutan perusahaan/corporate sustainability yang dikutip dari Dow Jones Sustainability
Indexes (2012) merupakan "pendekatan bisnis yang menciptakan nilai pemegang saham jangka panjang dengan merangkul peluang dan mengelola risiko yang berasal dari perkembangan ekonomi, lingkungan, dan sosial" (Taticchi, 2013). Keberlanjutan perusahaan sangat penting untuk bisnis untuk keberhasilan jangka panjang perusahaan dan untuk memastikan bahwa pasar memberikan nilai di seluruh masyarakat. Agar dapat berkelanjutan, perusahaan harus beroperasi secara bertanggung jawab sesuai dengan prinsip universal dan mengambil tindakan yang mendukung masyarakat sekitarnya (United Nations, n.d.).

Perusahaan batubara dalam film "Sexy Killers" tersebut haruslah memenuhi konsep keberlanjutan ekonomi, lingkungan dan sosial, bukan hanya keberlanjutan ekonomi saja yang telah dipenuhi dalam hal keuntungan perusahaan. Dengan adanya konsep lingkungan, PT Toba Bara Sejahtra memikirkan generasi mendatang demi kebutuhan sumber daya dalam jangka panjang untuk memastikan kualitas hidup dari generasi masa depan demi meraih keberhasilan jangka panjang perusahaan. Selain itu konsep sosial kepada masyarakat perlu diterapkan dengan kepedulian perusahaan yang tulus terhadap hak asasi mereka berupa pemberian kehidupan yang layak seperti kebersihan air dan udara. Cara perusahaan untuk melakukan pemenuhan ini harus disertai dengan komitmen yang tinggi dengan melaporkan upaya yang telah mereka lakukan dimana mereka melakukan proyek dan melakukan pemulihan atau kepedulian. PT Toba Bara Sejahtra harus memiliki prinsip sosial, ekonomi, dan lingkungan dalam melakukan bisnisnya agar dapat bertahan di masa depan dan didukung masyarakat. Meskipun efek kepedulian perusahaan ini memiliki waktu yang lama dan tidak memiliki efek langsung, namun agar perusahaan tersebut menjadi sustain maka diperlukan kepedulian perusahaan terhadap stakeholders yang berkaitan. 


\section{Simpulan}

Berdasarkan analisis di atas dapat disimpulkan bahwa perusahaan tambang batubara dalam film "Sexy Killer" masih belum memenuhi kriteria dari corporate citizenship yang diidentifikasikan oleh Caroll. Sejumlah pelanggaran HAM dan Undang-Undang mengenai lingkungan hidup juga masih terbatas penerapan hukumnya terhadap perusahaan dikarenakan masih adanya aktivitas yang melanggar hukum dan HAM tanpa diadili. Perusahaan batubara dalam kasus ini belum mampu memberikan timbal balik yang baik kepada masyarakat yang sesuai dengan prinsip pembangunan perusahaan yang berkelanjutan agar diterima dalam jangka waktu yang panjang oleh masyarakat dan bisa bertahan sebagai perusahaan yang tidak hanya mengandalkan keuntungan saja, tapi juga etika.

\section{DAFTAR PUSTAKA}

Ambarini, N. S. B. (2011). Audit Lingkungan sebagai Perwujudan Tanggung Jawab Sosial Perusahaan (Corporate Social Responsibility) di Era Globalisasi Ekonomi. Jurnal MasalahMasalah Hukum, 40(1), 93-101.

Ayu, O. D. (n.d.). Menjaga Lingkungan Hidup Untuk Pemenuhan Hak Asasi Manusia. Retrieved from http://ham.go.id/menjaga-lingkunganhidup-untuk-pemenuhan-hak-asasimanusia/

Carroll, A. B. (2003). The Four Faces of Corporate Citizenship. Business and Society Review, 100(101), 1-7.

Drisko, James W. \& Maschi, T. (n.d.). Content Analysis. Oxford: Oxford University Press.

Indonesia, W. (n.d.). Hak asasi manusia. Retrieved from http://www.watchindonesia.org/about$\mathrm{u} /$ work-fields/conflict-preventionresolution?lang=ID
Kartika, H. (2019). Pendapatan Toba Bara (TOBA) melonjak $41,11 \%$ pada tahun lalu, berikut penopangnya. Retrieved from

https://investasi.kontan.co.id/news/pend apatan-toba-bara-toba-melonjak-4111pada-tahun-lalu-berikut-penopangnya.

Klaris, T. (2018). To The Concept of Sustainable Development: From its Beginning to the Contemporary Issues. Zagreb International Review of Economics \& Business, (1), 67-94.

Republik Indonesia. Undang-undang Republik Indonesia Nomor 39 tahun 1999 tentang Hak Asasi Manusia (2019). Indonesia: https://www.komnasham.go.id/files/147 5231474-uu-nomor-39-tahun-1999tentang-\$H9FVDS.pdf. Retrieved from https://www.komnasham.go.id/files/147 5231474-uu-nomor-39-tahun-1999tentang-\$H9FVDS.pdf

Rochmani. (2015). Perlindungan atas Hak Lingkungan Hidup yang Baik dan Sehat di Era Globalisasi. Jurnal MasalahMasalah Hukumasalah Hukum, 44(1), 18-25.

Siombo, M. R. (2013). Arah Politik Hukum Lingkungan di Indonesia. Jurnal Masalah-Masalah Hukum, 42(3), 381389.

Syahni, D. (2019). Sexy Killer, Ketika Industri Batubara Hancurkan Lingkungan dan Ruang Hidup Warga. Retrieved from https://www.mongabay.co.id/2019/04/1 6/sexy-killer-ketika-industri-batubarahancurkan-lingkungan-dan-ruanghidup-warga/.

Taher, A. P. (2019). Respons Luhut ke Sexy Killers: Bukan Sikap Menteri Tapi Pengusaha. Retrieved from https://tirto.id/respons-luhut-ke-sexykillers-bukan-sikap-menteri-tapipengusaha-dm $1 \mathrm{Z}$. 
Taticchi, P. . et. a. (2013). Sustainability Measurement and Reporting: Impacts on Finance, Stakeholders Communication and Internal Measurement Practices. Corporate Sustainability, CSR, Sustainability, Ethics \& Governance. Berlin: SpringerVerlag Berlin Heidelberg.

Toba Bara. (n.d.). Tentang Toba Bara. Retrieved from http://www.tobabara.com/id/sekilas- perusahaan/tentang-toba-bara/selamatdatang-di-website-toba-bara/

United Nations. (n.d.). Guide to Corporate Sustainability: Shaping a Sustainable Future. United Nations Global Compact.

Watchdoc Image. (2019). Sexy Killers (Full Movie). Retrieved from https://www.youtube.com/watch?v=qlB $7 \mathrm{vg} 4 \mathrm{I}-\mathrm{To} \& \mathrm{t}=1 \mathrm{~s}$ 